\begin{tabular}{|c|c|c|}
\hline & Int.J.Curr.Microbiol.App.Sci (2021) 10(10): 326-338 & \\
\hline EXCELLENT & $\begin{array}{l}\text { International Journal of Current Microbiology and Applied Sciences } \\
\text { ISSN: 2319-7706 Volume } 10 \text { Number } \mathbf{1 0}(\mathbf{2 0 2 1 )} \\
\text { Journal homepage: http://www.ijcmas.com }\end{array}$ & $\begin{array}{l}9 \\
39\end{array}$ \\
\hline PUBLISHERS & & www:ijcmas.com \\
\hline
\end{tabular}

Review Article

https://doi.org/10.20546/ijcmas.2021.1010.041

\title{
A Review on Biochar Production and its Applications in Agriculture
}

\author{
P. M. Sameera ${ }^{1}$, A. Suresh ${ }^{2 *}$, J. Chapla $^{3}$ and P. Raja Rao ${ }^{2}$ \\ ${ }^{1}$ Department of Environmental Science, Sarojini Naidu Vanita Pharmacy \\ Maha Vidyalaya, India \\ ${ }^{2}$ Department of Biotechnology, ${ }^{3}$ Department of Environmental Science, University College of \\ Technology, Osmania University, Hyderabad, Telangana State, India \\ *Corresponding author
}

A B S T R A C T

Keywords

Agriculture,

Composting, soil

health, biochar

Article Info

Accepted:

15 September 2021

Available Online:

10 October 2021
Amazonians are the pioneer workers in put in their effort to increase the soil fertility and productivity by the use of biochar. Biochar is nothing but life from charcoal. Few decades ago it is a common practice for the farmers to burn the plants after harvest. Though the farmers are not aware of the importance of biochar they felt that they are irradiating different kinds of infections and diseases and also the insects. This way the farmers are indirectly helping themselves by improving the soil texture, fertility and also productivity of the crop. The production of biochar is anerobic process. The biochar can be obtained from different crop residues which may be from black or red soils. Biochar is nothing but carbon stable form and it can remain in soil for decades.

\section{Introduction}

The usage of biochar was introduced by Amazonians to increase the soil fertility and productivity. Biochar is a stable rich carbon, solid and remains in soil for decades "bio" means life and it is from "biomass" and char means charcoal. In olden days from combined state of Andhra Pradesh it was the practice of the farmers to burn the residues of crops that is after harvest to clean the whole field from insects that is to attract the insects to the flames and kill them and also infected soil born diseases, without knowing the importance of biochar that means indirectly it helped them in improving the soil fertility and improved the yield for the next crop. Sometimes we see the burning of forest by rupturing the branches which is a natural phenomenon and forms biochar and helps in increase the soil fertility and also increase retention of moisture content and porosity of soil naturally. Biochar is obtained from biomass by pyrolysis, biomass of plants is heated at $300-1000^{\circ} \mathrm{C}$ creates biochar which is stable carbon compound (Lehmann and Joseph 2009). Biochar is different from charcoal which is naturally formed and 
charcoal is used as fuel to produce heat. The great property of biochar is it will not release carbon for years together in turn increases the microbial activity in the soil (Aditya Parans et al., 2014). Biochar helps in increase the soil fertility that means the productivity of the crop increases not only this it gives protection to some of the soil microbial infectious organisms. The Amazonians used to burn the plant biomass in the trenches or in pits. The formation of biochar is through anaerobic process that means absence of oxygen in turn which produces biochar, bio-oil and gas products. This gas is called syngas the yield is $60 \%$ bio-oil $20 \%$ biochar and 20\% syngas. Where as the slow process of pyrolysis of biomass will yield $50 \%$ char that means the contribution towards the soil fertility is high, this is eco friendly process without any side effects.

According to different estimates, 72-127 Mt of crop residues are burnt on-from India (Pathak et al., 2010). Open field burning of crop residues is perceived as an age old practice to boost soil fertility in terms of $\mathrm{P}$ and $\mathrm{K}$, but often leads to a loss of other nutrients (eg. N and $\mathrm{S}$ ), organic matter and microbial activity required for maintaining better soil health. On the other hand, maintenance of a threshold level of organic matter in rainfed soil is crucial to sustain soil physical, chemical and biological activities to achieve optimum agricultural production and environmental functions (Grace, 2008).

Almost any form of organic resources can be pyrolyzed into biochar including various types of forest residues (Xu et al., 2013), agricultural residues (eg. corn cob, corn stalk, wheat straw, rice straw, stalk of pearl millet, cotton, mustard, soybean and sugar beet tailing) (Singh et al., 2012; Zhao et al., 2013; Purakayastha et al., 2015), and agro-industrial waste (paper mill waste, Jatropha husk, coffee husk, coconut shell and cocoa pod husk)
(Munongo et al., 2017). Biochar production protocols in India are yet to be standardized.

A low cost portable biochar kiln with proper design and operational process can be considered as an economically viable option for rainfed areas in developing countries for efficient recycling of unused and excess crop residues. Crops are maize, castor, cotton, pigeonpea and agroforestry Gliricidia twig, Eucalyptus bark, Pongamia shell, Eucalyptus twig and Leucaena twig residues were chosen as raw materials for biochar production due to their wide availability in rainfed areas of India, which otherwise are mostly burnt in field and for their differences in composition.

No information is available on biochar production technology for these crop residues, and also physic-chemical characteristics of biochar produced from such crops. Further, there were very few studies has been done in India on the effects of biochar produced from different residues and under different pyrolysis conditions on soil and crops (Singh et al., 2013; Jothiprakash and Palaniappan, 2014; Sekar et al., 2014; Prabha et al., 2015).

Large quantities of crops and agro forestry residues that are wood residues are in metric tons per annum (MNRE 2009 25, 26 IARI, 2012). The Crop residues in India as follows bajra, cotton, ground nut, jowar, maize paddy, sugarcane, sunflower, green gram, black gram, toordal and chilli (Andra Pradesh and Telangana State). The above crops generally grow in black \& red soils with high content of clay, these soils have less porosity under moisture retention capacity. The regular usage of chemical fertilizers and pestisides reduces the soil fertility in long run. To maintain sustainability of the soil fertility without any side effect usage of biochar is economically viable and also to increase the soil porosity, moisture retention capacity and the soil fertility. 
The soils are highly contaminated due to various anthropogenic activities which will affect the fertility of the soil inturn, will have great impact on the growth of plant and also the produce. That means the availability of nutrients of the soil will decrease and also the strength of soil. The nutrient values decrease after the harvest of crop, further degrade the soil fertility for future crops too. The chemical fertilizers and some of the pesticides have a marked effect on not only the properties of soil but also on the microorganisms of the soil, due to long persistence of chemicals the soil bacteria and some useful fungi will show a decline in their existence. The biofertilizers may increase the growth of bacterial groups for the sustenance of the soil fertility. The biofertilizer may not have negative impact towards soil structure nor soil fertility. Whereas the biochar has rich carbon organic material which is obtained from bio-mass of the plants, such as wood, leaves, stems and many types of manures etc., biochar also can be made from animal waste, chicken waste, dairy waste and also from animal bone. The biochar has the capacity of sustainable approach and improves soil quality as well as enhance the plant growth this process shows that biochar play a key role in sustainable development of agriculture. With this biochar nutrient deficiency of the soil can overcome. The municipal waste may be burnt by pyrolysis method but there is every possibility of emitting toxic chemicals which cannot be used in agricultural fields.

\section{Biochar-Biomass raw material}

The conversion of biomass to biochar takes place in the absence of oxygen. The raw materials of biomass to convert into biochar are plants, grasses, rice husk, corn stalks, cotton twigs, dried plant parts, sugarcane, rice straw, tree bark, wood chips, seeds, peels and crop residues etc., biochar is mainly composed of cellulose and hemicellulose. The temperature plays a role in the formation of biochar. The solid biomass converts in to biochar in this process oil and also volatile gases are emitted.

\section{Properties of biochar}

Biochar is nothing but carbon stable form and it can remain in the soil for years together, this reduces the emission of green house gases from carbon sequestration. The properties of biochar varies depends on the crop materials involved in the decomposition of biomass.

The physical properties of biochar will have the amendment and effects on functioning of the environment. This will help in soil quality and soil fertility, improve the retention of soil moisture, soil aeration, not only this it attracts soil microorganisms. The application of biochar in agricultural field and the results of enhancement of crop yield is only satisfactory.

\section{Chemical properties}

It was clear that the biochar increases the $\mathrm{pH}$ of the soil that is reduce the soil acidity, enhances the retention of nutrients and fertilizers.

Mixing of biochar with different soil or with manure or compost improve the efficiency of the crop soils and reduces the application of manures. The nature of biochar is it protects the leaching of nutrients. Biochar can also be mixed with liquid manures.

Biochar obtained by slow pyrolysis from biomass waste with the primary goal of soil improvement (Lehmann et al., 2006), is highly porous, fine-grained, carbon dominant product rich in paramagnetic centers having both organic and inorganic nature, with large surface area possessing oxygen functional groups and aromatic surfaces (Atkinson et al., 2010). 


\section{Characteristics of biochar}

From a physical point of view, biochar has a low bulk density due to its porous structure leading to a high specific surface area ranging from $50-900 \mathrm{~m}^{2} \mathrm{~g}-1$ (Schimmelpfennig and Glaser, 2012), and a high water holding capacity (Glaser et al., 2002). From a chemical point of view, the most striking feature of biochar is its polycondensed aromatic structure (Glaser et al., 1998) caused by dehydration during thermo chemical conversion (Schimmel-pfennig and Glaser, 2012) leading to its black color. This structure is also responsible for its relative recalcitrance compared to other organic matter in the environment. In addition, basic ash components lead to a high $\mathrm{pH}$ values. Several studies demonstrated that the quality of the feedstock and production conditions such as pyrolytic temperature and residence time has a significant influence on the quantity, quality and the elemental compositions of the biochar (Naeem et al., 2014; Dume et al., 2015). Therefore, selection of suitable feedstock and optimum pyrolytic protocol is crucial for biochar producers to produce a planned biochar amendment that is modified to improve a specific soil issue in agriculture. Low temperature biochar has high volatile matter (VM) content, but lower fixed carbon (FC) and ash contents than the high temperature biochar (Bourke et al., 2007).

Total C, fixed carbon (FC) and ash content of the biochar is more dependent upon the feedstock than the pyrolysis temperature, while Volatile matter (VM) and biochar yield are sensitive to pyrolysis temperature (Deenik et al., 2010). Xiong et al., (2014) observed that cotton stalk biochar yield decreased from 37.35 to $31.23 \%$, VM content decreased from 30.23 to $13.76 \%$ and the FC yield increased from 64.12 to $76.63 \%$ as the carbonization temperature increased from 400 to $800^{\circ} \mathrm{C}$. Depending on feedstock sources and temperature conditions, biochars exhibit large ranges in porosity and bulk density (BD) (Rogovska et al., 2014). Increased pyrolysis temperature results in a dramatic rise in porosity (Bird et al., 2011) due to increases in dehydroxylation of water molecules resulting in the formation of pores on the surface of biochar (Narzari et al., 2015) and decrease in BD of biochar (Rogovska et al., 2014) due to greater proportion of biochar particles with smaller particle size distributions (Kim et al., 2012). Purakayastha et al., (2015) reported that the $\mathrm{BD}$ of rice and wheat straw biochar was lower than that of maize stover and pearl millet stalk biochar. The water holding capacity was highest in wheat straw biochar $(56 \%)$ than biochar prepared from maize stover (45\%) and pearl millet stalk (41\%). Several reports state that $\mathrm{pH}$ (Yu et al., 2014; Narzari et al., 2015) and EC (Singh et al., 2010;Naeem et al., 2014) of biochars increased with increasing pyrolysis temperatures. High $\mathrm{pH}$ values of biochar may be due to hydrolysis of carbonates and bicarbonates of base cations such as $\mathrm{Ca}, \mathrm{Mg}$, $\mathrm{Na}$ and $\mathrm{K}$ present in the source materials (Gaskin et al., 2008) and greater separation of basic cations and organic anions from organic materials with increase in pyrolysis temperature (Yuan et al., 2011). Yu et al., (2014) reported that the EC of the crop straw derived biochars increased with increasing pyrolysis temperature.

\section{Effects of biochar in agricultural soil}

Biochar production and application to soil enhances the rate of soil carbon sequestration through shift from short-term bio-atmospheric carbon cycle to the long-term geological carbon cycle (Lehmann et al., 2011). Many studies and reviews have highlighted the potential advantages of biochar application as soil amendment (Sohi et al., 2010) covering benefits beyond carbon sequestration. This includes improvement of soil physical 
properties that benefit crops (Bhattarai et al., 2015; Ajayi and Horn, 2016), improved retention and availability of soil nutrients (Dume et al., 2016), improved biological activity, by providing metabolizable organic $\mathrm{C}$ substrates (Demisie and Zhang, 2015; Hersztek et al., 2016) and consequently higher crop yields (Purakayastha et al., 2015; Laghari et al., 2016) and societal advantages through mitigation of global warming by carbon sequestration (Garcia et al.,2016; Zhang et al., 2017). These benefits provide the basis for up scaling of biochar use in rainfed agriculture. Globally, few studies have focused on the use of biochar in rainfed areas (Mulcahy et al., 2013; Laghari et al., 2016). Very little amount of biochar is derived from crop residues are utilized in Indian agriculture.

\section{Mitigation of climate change}

Biochar has the potential to counter climate change because the inherent fixed carbon in raw biomass that would otherwise degrade to greenhouse gases is sequestered in soil for years. In recent years the use of surplus organic matter to create biochar has yielded promising results in sequestration of carbon. Lehmann et al., (2006) estimated biochar production from forestry and agricultural wastes. In India, biochar from residues of maize, castor, cotton and pigeonpea can sequester about 4.6 Mt of total carbon annually in soil, making it a carbon sequestering process (Venkatesh et al., 2015). A number of studies have reported on environmental benefits of biochar additions which will reduce emission of non- $\mathrm{CO}_{2}$ greenhouse gases by soil (Zwieten et al., 2010) that could be due to inhibition of either stage of nitrification and/ or inhibition of denitrification, or promotion of the reduction of $\mathrm{N}_{2} \mathrm{O}$; increases $\mathrm{CH}_{4}$ uptake from soil (Rondon et al., 2006) and long-term carbon sequestration in soil (Srinivasa Rao et al., 2013).

\section{Soil health}

Numerous studies have reported on the beneficial impacts of biochar addition on soil health improvement and GHG emissions reduction which are of critical importance in tropical environments in combating climate change induced drought and to improve soil health. Biochar additions have positive effects on the soil health directly and indirectly. The incorporation of biochar into soil alters soil physical properties like bulk density, penetration resistance, structure, macroaggregation, soil stability, pore size distribution and density with logical implications in soil aeration, wettability of soil, water infiltration, water holding capacity, plant growth and soil workability; positive gains in soil chemical properties include: retention of nutrients, enhances cation exchange capacity and nutrient use efficiency, decreases soil acidity, decreases uptake of soil toxins and increases the number of beneficial soil microbes.

\section{Nutrient use efficiency}

Knowledge on the link between biochar function and its interaction with nutrient elements and crop roots may throw light on understanding fertilizer use efficiency. The enhanced nutrient retention capacity of biochar-amended soil not only reduces the total fertilizer requirements but also copes up the climate and environmental impact on crops. Biochar significantly increases the efficiency and reduces the need for traditional chemical fertilizers with sustainable crop yields. Addition of biochar to soil alters important soil chemical qualities; soil $\mathrm{pH}$ increased towards neutral values, typically increased soil cation exchange capacity. Glaser et al., (2002) observed increasing trend of bio-available $\mathrm{P}$ and base cations in biochar applied soils. Biochar application boosts up the soil fertility and improves soil quality by 
raising soil $\mathrm{pH}$, increasing moisture holding capacity, attracting more beneficial fungi and microbes, improving cation exchange capacity and retaining nutrients in soil (Lehmann et al., 2006). The immediate beneficial effects of bio-char additions on nutrient availability are largely due to higher potassium, phosphorus and zinc availability and to a lesser extent of calcium and copper (Lehmann et al., 2003). Biological nitrogen fixation by common beans was increased from 50 to $72 \%$ of total nitrogen uptake with increasing rates of biochar additions $(0,31,62$, and $93 \mathrm{t} \mathrm{C}$ ha-1) to a low-fertility Oxisol (Rondon et al., 2007). A beneficial impact of biochar on the plantavailable phosphorus has been recorded in soils enriched with biochar, which in contrast to ammonium, is not a characteristic generally associated with soil organic matter (Steiner et al., 2007). For agronomic purposes, biochar applied with $\mathrm{N}$ fertilizer, helps to counter the potentially unavailable biochar $\mathrm{N}$ (Steiner $e t$ al., 2008).

\section{Soil microbial activity}

Biochar provides a suitable habitat for a large and diverse group of soil microorganisms. A higher retention of microorganisms in biochar amended soils may be responsible for greater activity and diversity due to a high surface area as well as surface hydrophobicity of both the microorganisms and biochar. A strong affinity of microbes to biochar can be expected since the adhesion of microorganisms to solids increases with higher hydrophobicity of the surfaces. Biochar is an effective to activate living things and improve natural environment. Carbonized biomass such as rice husk charcoal or wood ash have been valuable material as soil amendment. The optimal biochar combining fertilizer and carbon storage function in soils would activate the microbial community leading to nutrient release and fertilization and would add to the decadal soil carbon pool
(Venkatesh et al., 2018). Biochar's inherent physical quality contributes to the improvement in the soil porosity (Lammirato et al., 2011), surface area (Lammirato et al., 2011) and soil aeration (Sun et al., 2013), thereby improves aerobic activity like methane oxidation (Karhu et al., 2011). Applied biochar may provide habitats for growth of soil dwelling microorganisms (Kookana et al., 2011; Tong et al., 2014) and protect them against natural predators (Thies and Rillig, 2009). Literature on enzyme activities in biochar-amended soils are limited, but few existing results showed variable data depending on biochar properties and soil characteristics (Bailey et al., 2011). Masto et al., (2013) reported maximum increase in activities of dehydrogenase (21\%), acid phosphatase $(32 \%)$ and alkaline phosphatase $(22.8 \%)$ at the highest Eichornia biomass biochar dose of $20 \mathrm{~g} \mathrm{~kg}-1$. In a similar study in red soil with Parthenium hysterophorus (L.) biochar, Kumar et al., (2013) reported a highest DHA of $1071 \mathrm{mg}$ TPF kg-1 $24 \mathrm{~h}-1$ for 20 g kg-1 Parthenium hysterophorus (L.) biochar. In contrast to DHA, the response of alkaline and acid phosphatase showed decreased activity at 5 and $1 \mathrm{~g} \mathrm{kg-1}$ of Parthenium hysterophorus (L.) biochar, respectively.

\section{Soil and water conservation}

The mineral and organic components of soil contribute to soil water holding capacity, but only the latter can be actively managed. Water is held more tightly in small pores, so clayey soils retain more water. The lower soil bulk density generally associated with higher soil organic matter is a partial indication of how organic matter modifies soil structure and pore size distribution. The intrinsic contribution of biochar on soil physical parameters such as wet ability of soil, hydraulic conductivity, water infiltration, water retention, macro aggregation and soil stability are invariably 
related to $\mathrm{SA}$, porosity, $\mathrm{BD}$ and aggregate stability and are critically important in tropical environments in combating erosion, mitigating drought and nutrient loss and in general to enhance groundwater quality. Several studies have reported alterations in WHC and water retention in biochar-amended soils with as low as $0.5 \%(\mathrm{~g} g-1)$ biochar application rate sufficient to improve WHC.

A long-term column study indicated that biochar-amended Clarion soil retained up to $15 \%$ more water, and $13 \%$ and $10 \%$ more water retention at $-100 \mathrm{kPa}$ and $-500 \mathrm{kPa}$ soil matric potential, respectively, compared to unamended controls (Laird et al., 2010). Tryon (1948) reported that application of biochar increased AWC in sandy soil, no effect in a loamy soil, and decreased moisture content in a clayey soil. Such a response may be attributed to the hydrophobic nature of the charcoal and to alterations in PSD. Because the soil moisture retention may only be improved in coarse-textured soils, a careful choice of biochar/soil combination needs to be taken into consideration (Tryon, 1948).

\section{Environmental impact of biochar}

Biochar is a straight forward nonetheless powerful tool to combat temperature change. Biochar sequestration is taken into account carbon negative because it ends up in a web decrease in atmospherical greenhouse emission over centuries or millennia time scales. It will build a giant distinction within the fuel emissions worldwide and act as a significant player within the international carbon market with its sturdy, clean and straightforward production technology. As organic materials decay, gases like greenhouse emission and paraffin which is twenty one times stronger as a greenhouse gas than $\mathrm{CO}_{2}$ square measure free into the atmosphere. Rather than permitting the organic come to decompose and emit greenhouse emission, transmutation will be wont sequester the carbon and take away current greenhouse emission from the atmosphere and store it in nearly permanent soil carbon pools, creating it a carbon-negative method. By charring the organic material, a lot of carbon becomes "fixed" into lot of stable kind, and once the ensuing biochar is applied to soils, the carbon is effectively sequestered.

It's calculable that use of this methodology to 'tie up' carbon has the potential to scale back current international carbon emissions by the maximum amount as ten p.c. the utilization of transmutation conjointly provides a chance for the process of agricultural residues, wood wastes and municipal solid waste into helpful clean energy.

Though some organic matter is critical for agricultural soil to take care of its productivity, a lot of agricultural waste will be turned directly in to biochar, bio-oil and syngas. Biochar may also give a particularly powerful suggests that of reversing geological process. In most semi-arid and desert climates the soil is sort of potential to absorb huge quantities of carbon. Generally, the quantity of carbon within the soil could be a direct indication of soil quality: the bigger the quantity of soil organic carbon, the upper quality is the soil.

Higher carbon stocks have an immediate correlation with augmented agricultural yields, higher plant wetness absorption, improved soil tilth and better levels of soil biological activity.

\section{Best management practices for biochar soil application}

The particle size distribution of biochar materials can vary wide reckoning on the feedstock and therefore the transformation technique accustomed manufacture the 
biochar. With little particles, it's vital to use biochar in ways which minimize loss thanks to wind or water erosion. Some best management practices area unit noncommissioned below to avoid these losses.

Apply biochar under proper weather conditions when winds are gentile. It varies according to general weather and time of day. Use of biochar throughout drizzling conditions, that is light-weight rain can dampen biochar dirt and hold it on the soil surface till it is plowed in.

Apply wet biochar. Water is applied on biochar or it is mixed with damp manure.

Manufacture a biochar formulation by pelleting, prilling and mixture biochar with alternative forms of amendments like manures or composts. Totally different biochar formulations are best suited to different application strategies, and really fine biochar could also be fascinating in bound cases as an example once applying as suspension by itself or mixed with manure.

\section{Application rate of biochar}

Recommended application rates for any soil modification should be supported intensive field testing, soil sorts and crops.

Also, biochar materials will dissent wide in their characteristics, so the character of a particular biochar material (e.g. pH, ash content) conjointly influences application rate.

Application rates of 5-50 tonnes of biochar per square measure $(0.5-5 \mathrm{~kg} / \mathrm{m} 2)$ with applicable nutrient management leads to higher yield of crops. Most biochar materials aren't substitutes for fertiliser, thus adding biochar while not necessary amounts of element (N) and alternative nutrients cannot be expected to produce enhancements to crop yield.

\section{Size of biochar particles}

Ideal particle sizes to enhance soil wet retention haven't however been determined. Handling and applying the biochar also will impact the choice of what particle size is best.

Biochar is finely divided and may be applied to soil because it is, provided care is taken to attenuate wind lose. If particle size should be reduced, it is hand crushed within luggage employing a massive pestle. Little amounts also can be crushed by driving over the fabric with a roller force by a tractor. For crushing larger amounts of biochar materials, hammer mills are used, still as compost shredders. Best management imply embrace wetting fabric before crushing it to cut back dirt created throughout the method and crushing the biochar within closed luggage.

\section{Frequency of Application}

Due to its intractableness to decomposition in soil, single applications of biochar will give useful effects over many growing seasons within the field. Therefore, biochar doesn't to be applied with every crop, as is sometimes the case for manures, compost and artificial fertilizers. Counting on the target application rate, offer the provision of the biochar supply and therefore the soil management system, biochar amendments are often applied in increments. However, it's believed that useful effects of applying biochar to soil improve with time, and this could be taken into thought once rending applications over time.

\section{Agricultural Applications}

The potential edges that biochar offers for forming includes;

Improved soil fertility and crop yield.

Increased fertiliser use potency 
Improved water retention, aeration and soil tilth

Higher ion exchange capability and fewer nutrient runoff

Clean and economical biomass energy production from crop residues and forest trash

Combined heat, power and refrigeration opportunities from pyrolosis

Leads to web sequestration of carbon from the atmosphere to the soil thereby increasing soil organic carbon (SOC)

Greater on-farm profit.

Can be supported through carbon markets and carbon offsets

Decreased inhalation anesthetic and alkane emissions from soils

Provides powerful tool for reversing geological process

Provides different for slash-and burn agriculture

Can work as element of renewal and aforestation efforts

Can turn out electricity, boil-oils and atomic number 1 fuels

Can use big variety of feedstock together with crop residues like wheat and corn straw, poultry litter, cow manure, forest trash and different farm-based biomass resources

Act as a liming agent to scale back acidity of soils

Carbon sequestration by the natural action of chemical change

Net production of energy in kind of bio energy
Methods of Biochar Application under conventional field crop system (Parmar et al., 2014)

\section{Broadcast and incorporate}

Broadcasting is done by hand on small scales or on larger scales by victimisation lime/solid manure spreaders or broadcast seeders. Moistened biochar materials are more suited to application with manure spreaders than lime spreaders. Incorporation is achieved by any tilling methodology at any rate, as well with hand hoes, animal draft ploughs, disc harrows, chisels, rotary hoes, etc. Mould board ploughing is not advised because it is unlikely to combine the biochar into the soil and end up in deep biochar layers.

\section{Traditional banding}

Banding of seeds and fertilizers could be a routine operation in mechanized agriculture, and involves modification in an exceedingly slender band, typically improper use of instruments that cuts the soil open. Stripe permits biochar to be placed within the soil whereas minimizing soil disturbance, creating it potential to use biochar when crop institution.

However, the quantity of biochar that may be applied during this approach area unit not up to those which may be achieved by broadcast applications. Once operating by hand, biochar is applied in furrows opened a hole and closed when applying biochar.

\section{Mixing biochar with other solid organisms}

Mixing biochar with different soil amendments like manure, compost or lime before soil application will improve potency by reducing the number of field operations needed. Since biochar has been shown to soluble nutrients and obstructing them against 
action, co-mixing with biochar could improve the potency of manure in different periods or different seasons of applications.

\section{Mixing biochar with liquid manures}

Biochar can even be mixed with liquid manures and applied as fine biochars can probably be best suited to the present kind of application mistreatment existing application instrumentality, and mud issues related to these would be self-addressed.

Biochar might even be mixed with manure in holding ponds and will probably cut back gaseous chemical element losses because it will once applied to soil.

In olden days unknowingly the farmers used to burn the residues of the plants in agricultural fields thinking that they are able to irradiated the fungal infections and some plant diseases not only this to wipe out the insects and pests.

But this process directly helped the farmers in increase in the soil texture that is the increase in the poracity of the soil particles which helped in retaining soil moisture and soil air, allowing the plant root penetrate easily.

The biochar is nothing but a carbon compound which can retain in the soil for generations the biochar improves the soil properties, also improves soil nutrients retention, improves the biological activities and also cat ion exchange capacity.

The use of biochar in the agriculture fields will differently reduce the usage of traditional chemical fertilizers. The application of biochar has an impact on the growing crops for number of seasons. The application of biochar should be on the basis of weather conditions. The biochar is natural, ecofriendly and without any harming the environment.

\section{References}

Aditya Parmar, Prabhat K., Nema and Tripti Agawal (2014). Biochar production from agro-food industry residues: a suitable approach for soil and environmental management., Current Science 107(10): 1673-1682.

Ajayi A E and Horn R (2016). Modification of chemical and hydrophysical properties of two texturally differentiated soils due to varying magnitudes of added biochar. Soil and Tillage Res. 164: pp 34-44.

Atkinson C J, Fitzgerald J D and Hipps N A (2010). Potential mechanisms for achieving agricultural benefits from biochar application to temperate soils: A review. Plant and Soil. 337(1): pp 1-18.

Bailey V L, Fansler S J, Smith J L and Bolton H (2011). Reconciling apparent variability in effects of biochar amendment on soil enzyme activities by assay optimization. Soil Biol. Biochem. 43: pp 296-301.

Bhattarai B, Neupane J, Dhakal S P, Nepal J, Gnyawali B, Timalsina R and Poudel A (2015). Effect of biochar from different origin on physiochemical properties of soil and yield of garden pea (Pisum sativum L.) at Paklihawa, Rupandehi, Nepal. World J. Agric. Res. 3(4): pp 129-138.

Bird M I, Wurster C M, Silva P, Bass A M and De Nys R (2011). Algal biochar- production and properties. Bioresour. Technol. 102: pp1886-1891.

Bourke J, Harris M, Fushimi M, Dowaki C, Nunoura K, Antal T and Jr MJ (2007). Do all carbonized charcoals have the same structure A model of the chemical structure of carbonized charcoal. Industr. Enginer. Che. Res. 46: pp 5954-5967.

Demisie W and Zhang M (2015). Effect of biochar application on microbial biomass and enzymatic activities in degraded red soil, African J. Agri. Res. 10(8): pp 755-766.

Dume B, Ayele D, Regassa A and Barecha G (2016). Interactive effects of biochar in soil related to feedstock and pyrolysis temperature. American-Eurasian J. Agric. Environ. Sci. 16 (3): pp 442-448.

Dume B, Berecha G and Tulu S (2015). Characterization of biochar produced at 
different temperatures and its effect on acidic Nitosol of Jimma, Southwest Ethiopia. Int. J. Soil Sci. 10(2): pp 63-73.

Garcia M S, Monedero M A S, Roig A, Cano I L, Moreno B, Benitez E and Cayuela M L (2016). Compost vs biochar amendment: a two-year field study evaluating soil $\mathrm{C}$ build-up and $\mathrm{N}$ dynamics in an organically managed olive crop. Plant and Soil. DOI 10.1007/s11104-016-2794-4.

Gaskin J W, Steiner C, Harris K, Das K C and Bibens B (2008). Effect of lowtemperature pyrolysis conditions on biochar for agricultural use. Trans. Am. Soc. Agric Biol. Eng. 51: pp 2061-2069.

Glaser B, Haumaier L, Guggenberger G and Zech W (1998). Black carbon in soils: the use of benzenecarboxylic acids as specific markers. Organic Geochemistry. 29: 811819.

Glaser B, Lehmann J and Zech W (2002). Ameliorating physical and chemical properties of highly weathered soils in the tropics with charcoal - a review. Biology and Fertility Soils. 35: 219-230.

Glaser B, Lehmann J and Zech W (2002). Ameliorating physical and chemical properties of highly weathered soils in the tropics with charcoal - a review. Biology and Fertility Soils. 35: 219-230.

Grace A J. Kusuma, K. L. Sharma A, B, Uttam Kumar Mandal A, Pravin N. Gajbhiye A, K. Srinivas A, G. R. Korwar A, V. Hima Bindu A, V. Ramesh A, Kausalya Ramachandran A and S. K. Yadav(2008). Evaluation of long-term soil management practices using key indicators and soil quality indices in a semi-arid tropical Alfisol. Australian Journal of Soil Research., 46:368-377.

Jothiprakash G and Palaniappan V (2014). Development and optimization of pyrolysis unit for producing charcoal. Int. J. of Agri. Environ. Biotechnology. 7(4): pp 863-868.

Karhu K, Mattila T, Bergstrom I and Regina K (2011). Biochar addition to agricultural soil increased $\mathrm{CH} 4$ uptake and water holding capacity - results from a shortterm pilot field study. Agric. Ecosyst. Environ. 140(1-2): pp 309-313.
Kim H K, Kim J Y, Cho T S and Choi J W (2012). Influence of pyrolysis temperature on physicochemical properties of biochar obtained from the fast pyrolysis of pitch pine (Pinus rigida). Bioresour. Technol. 118: pp 158-162.

Kookana R, Sarmah A, Zwieten L V, Krull E and Singh B (2011). Biochar application to soil: agronomic and environmental benefits and unintended consequences. Adv. Agron. 112: pp 103.

Laghari M, Hu Z, Mirjat M S, Xiao B, Tagar A A and $\mathrm{Hu} \mathrm{M}$ (2016). Fast pyrolysis biochar from sawdust improves the quality of desert soils and enhances plant growth. J. Sci. Food Agric. 96(1): pp 199-206.

Laird D A, Fleming P, Davis D D, Horton R, Wang B Q and Karlen D L (2010). Impact of biochar amendments on the quality of a typical Midwestern agricultural soil. Geoderma. 158: pp 443-449.

Lammirato C, Miltner A and Kaestner M (2011). Effects of wood char and activated carbon on the hydrolysis of cellobiose by bglucosidase from Aspergillus niger. Soil Biol. Biochem. 43: pp 1936-1942.

Lehmann J, Gaunt J and Rondon M (2006). Biochar sequestration in terrestrial ecosystems: A review. Mitig. Adapt. Strategies Global Change. 11(2): pp 395419.

Lehmann J, Gaunt J and Rondon M (2006). Biochar sequestration in terrestrial ecosystems: A review. Mitig. Adapt. Strategies Global Change. 11(2): pp 395419.

Lehmann J, Rillig M C, Thies J, Masiello C A, Hockaday W C and Crowley D (2011). Biochar effects on soil biota - A review. Soil Biol. Biochem. 43: pp 1812-1836.

Lehmann, J. and Joseph, S. (2009). Biochar for Environmental Management: Science and Technology. ES BEM 13-1 13/1/09.

Masto R E, Kumar S, Rout T K, Sarkar P, George J and Ram L C (2013). Biochar from water hyacinth (Eichornia crassipes) and its impact on soil biological activity. Catena. 111: pp 64-71.

Mulcahy D N, Mulcahy D L and Dietz D (2013). Biochar soil amendment increases tomato seedling resistance to drought in sandy 
soils. J. Arid Environ. 88: pp 222-225.

Munongo $\mathrm{M} \mathrm{E}$, Nkeng $\mathrm{G} \mathrm{E}$ and Njukeng $\mathrm{J} \mathrm{N}$ (2017). Production and characterization of compost manure and biochar from cocoa pod husks. Int. J. Adv. Scient. Res. Manage. 2(2): pp 26-31.

Naeem M A, Khalid M, Arshad M and Ahmad R (2014). Yield and nutrient composition of biochar produced from different feed stocks at varying pyrolytic temperatures. Pak. J. Agri. Sci. 51(1): pp 75-82.

Naeem M A, Khalid M, Arshad M and Ahmad R (2014). Yield and nutrient composition of biochar produced from different feed stocks at varying pyrolytic temperatures. Pak. J. Agri. Sci. 51(1): pp 75-82.

Narzari R, Bordoloi N, Chutia R S, Borkotoki B, Gogoi N, Bora A and Kataki R (2015). Biochar: An Overview on its production, properties and potential benefits. In: Biology, Biotechnology and Sustainable Development (Choudhury $\mathrm{H}$ ed.). Research India Publications, Delhi, India. pp 13-39.

Parmar A, Prabhat K N and Agarwal T (2014). Biochar production from agro-foor industry residues: a sustainable approach for soil and environmental management. Current Science. 107 (10): 1673-1682.

Pathak H, Bhatia A, Jain N and Aggarwal P K (2010). Greenhouse gas emission and mitigation in Indian agriculture $-\mathrm{A}$ review. In: ING Bulletins on Regional Assessment of Reactive Nitrogen, Bulletin No. 19 (Ed. Bijay-Singh), SCON-ING, New Delhi, 34 p.

Prabha B, Pugalendhi S and Subramanian P (2015). Design and development of semiindirect non-electric pyrolytic reactor for biochar production from farm waste. Ind. J. Agric. Sci. 85(4): pp 585-591.

Purakayastha T J, Kumari S and Pathak H (2015). Characterization, stability, and microbial effects of four biochars produced from crop residues. Geoderma. 239-240: pp 293-303.

Purakayastha, T. J., Pathak, H., Kumari, Savita. (2013). Stability of biochar carbon- Its implication on carbon sequestration and microbial activities in soil. In: Proc.100th Indian Science Congress, Part II, Abstracts of Oral Presentation.

Rogovska N, Laird A D, Rathke S J and Karlen D L (2014). Biochar impact on Midwestern Mollisols and maize nutrient availability. Geoderma, 230-231: pp 340-347.

Rondon M A, Lehmann J, Ramirez J and Hurtado M (2007). Biological nitrogen fixation by common beans (Phaseolus vulgaris L.) increases with biochar additions. Biology and Fertility of Soils. 43: 699-708.

Rondon M A, Molina D, Hurtado M, Ramirez J, Lehmann J, Major $\mathrm{J}$ and Amezquita $\mathrm{E}$ (2006). Enhancing the productivity of crops and grasses while reducing greenhouse gas emissions through biochar amendments to unfertile tropical soils. In: Proceedings of the 18th World Congress of Soil Science. Philadelphia, PA, July 9-15, 2006. Presentation No. 138-68.

Schimmelpfennig S and Glaser B (2012). One step forward toward characterization: some important material properties to distinguish biochars. J. Environ. Qual. 41: 1001-1013.

Sekar S, Ryan D. Hottle and Rattan Lal (2014). Effects of biochar and anaerobic digester effluent on soil quality and crop growth in Karnataka, India. Agric. Res. 3(2): pp 137147.

Singh, B. P., Cowie, A. L., Smernik, R. J., (2012). Biochar carbon stability in a clayey soil as a function of feedstock and pyrolysis temperature. Environ. Sci. Technol. 46, 11770-11778.

Sohi S, Krull E, Capel E L and Bol R (2010). A review of biochar and its use and function in soil. Adv. Agron. 105(1): pp 47-82.

Srinivasa Rao Ch, Gopinath K A, Venkatesh G, Dubey A K, Harsha W, Purakayastha T J, Pathak H, Pramod J, Lakaria B L, Rajkhowa D J, Sandip M, Jeyaraman S, Venkateswarlu B and Sikka A K (2013). Use of biochar for soil health management and greenhouse gas mitigation in India: Potential and constraints, Central Research Institute for Dryland Agriculture, Hyderabad, Andhra Pradesh. p 51.

Steiner C, Glaser B, Teixeira W G, Lehmann J, Blum W E H and Zech W (2008). Nitrogen retention and plant uptake on a 
highly weathered central Amazonian Ferralsol amended with compost and charcoal. J. Plant Nutr. Soil Sci. 171: pp 893-899.

Steiner C, Teixeira W G, Lehmann J, Nehls T, MaceDo J L V, Blum W E H and Zech W (2007). Long term effects of manure, charcoal and mineral fertilization on crop production and fertility on a highly weathered Central Amazonian upland soil. Plant and Soil. 291: 275-290.

Sun Z, Moldrup P, Elsgaard L, Arthur E, Bruun E $\mathrm{W}$, Nielsen H H, de Jonge L W. Direct and indirect short-term effects of biochar on physical characteristics of an arable sandy loam. Soil Sci. 178, 2013: pp. 465-473.

Thies J and Rillig M C (2009). Characteristics of biochar: biological properties. In: Biochar for Environmental Management: Science and Technology (Lehmann J, Joseph S. eds.). Earthscan Ltd, London: pp 85-105.

Tong H, Hu M, Li F, Liu C and Chen M (2014). Biochar enhances the microbial and chemical transformation of pentachlorophenol in paddy soil. Soil Biol. Biochem. 70: pp 142-150.

Tryon E H (1948). Effect of charcoal on certain physical, chemical, and biological properties of forest soils. Ecol. Monogr. 18: 81-115.

Venkatesh G, Srinivasa Rao Ch, Gopinath K A and Sammi Reddy K (2015). Low-cost portable kiln for biochar production from on-farm crop residue. Indian farming. 64(12): 9-12, 18.

Venkatesh G. Sammi Reddy K, Gopinath K A, Visha Kumari V and Chary R G (2018). Biochar for enhancing the soil, water and crop productivity in rainfed areas. In: Krishna Rao B, Sammi Reddy K, Visha Kumari V, Nagarjuna kumar R and Rejani
R. (eds.). Rainwater Management for Climate Resilient Agriculture in Drylands. ISBN: 978-93-8088.

Xiong S, Zhang S, Wu Q, Guo X, Dong A and Chen C (2014). Investigation on cotton stalk and bamboo sawdust carbonization for barbecue charcoal preparation. Bioresour. Technol. 152: pp 86-92.

Xu R K, Zhao A Z (2013). Effect of biochars on adsorption of $\mathrm{Cu}$ (II), $\mathrm{Pb}$ (II) and $\mathrm{Cd}(\mathrm{II})$ by three variable charge soils from southern China. Environ Sci Pollut Res 20(12):8491-8501.

Yu L, Jie J Y, Rong Z X, Tong L G, Xin Z L and Bo M H (2014). Improvement to maize growth caused by biochars derived from six feed stocks prepared at three different temperatures. J. Integr. Agric. 13(3): pp 533-540.

Zhang M, Cheng G, Feng H, Sun B, Zhao Y, Chen $\mathrm{H}$, Jing Chen J, Dyck M, Wang X, Zhang $\mathrm{J}$ and Zhang A (2017). Effects of straw and biochar amendments on aggregate stability, soil organic carbon, and enzyme activities in the Loess Plateau, China. Environ. Sci. Pollut. Res. DOI 10.1007/s11356-017-8505-8.

Zhang, A., R. Bian, Q. Hussain, L. Li, G. Pan, J. Zheng, X. Zhang, and J. Zheng. (2013). Change in net global warming potential of a rice-wheat cropping system with biochar soil amendment in a rice paddy from China. Agric. Ecosyst. Environ. 173:3745.

Zwieten V L, Kimber S, Morris S, Chan K Y, Downie A, Rust J, Joseph S and Cowie A (2010). Effects of biochar from slow pyrolysis of paper mill waste on agronomic performance and soil fertility. Plant and Soil. 327: 235-46.

\section{How to cite this article:}

Sameera, P. M., A. Suresh, J. Chapla and Raja Rao, P. 2021. A Review on Biochar Production and its Applications in Agriculture. Int.J.Curr.Microbiol.App.Sci. 10(10): 326-338. doi: https://doi.org/10.20546/ijcmas.2021.1010.041 